\title{
TRAINING DISCIPLINE AND RESPONSIBILITY: THE IMPLEMENTATION OF VALUES CLARIFICATION MODEL
}

\author{
Indah Mutiatul Karim ${ }^{1}$ and Ali Mustadi ${ }^{2}$ \\ ${ }^{1}$ Postgraduate of Universitas Negeri Yogyakarta \\ Yogyakarta, 55281, Indonesia \\ indahmutiatul@gmail.com \\ ${ }^{2}$ Education Elementary School Study Program, Universitas Negeri Yogyakarta \\ Yogyakarta, 55281, Indonesia \\ Ali_mustadi@uny.ac.id
}

\begin{abstract}
The purpose of this study was to describe the influence of value clarification model to train discipline and responsibility for the student at PGRI University. This research is quasi-experiment. The population of this research is all students at the PGRI University. The sample of this research by using simple random sampling technique. The data were analyzed using MANOVA Test followed by Bonferroni post hoc test using SPSS 22.0 program. The results showed there is the influence value clarification model to build students' attitude.
\end{abstract}

Keyword: value clarification model, discipline, responsibility 


\section{Introduction}

Independence Indonesia did not escape the multiplicity of roles of younger generations who fought for the destiny of the nation out of colonial occupation. It shows how a great and powerful character of the nation to achieve independence so that it can enjoy a wealth of natural resources and all the potential that's there. The younger generation of Indonesia nation which has enjoyed independence continued and defend the country's independence. A form of business that can be done by the younger generation i.e. filling independence nation Indonesia with a wide range of achievements in the world scene.

The term young generation is always synonymous with various identity search euphoria in his time. Instability of adolescence external influences will be so easily metal reactions in various activities. Starting from Teen activities closely with the duty to study learning and achievement to the issues the involvement of adolescents in criminal offenses and criminal acts of crime in a row of news coverage of the mass media as well as media Electronics. Based on the Police Headquarters in Indonesia "Indonesia statistics report the year 2015" in 2015 a number of 352,936 cases (Statistics Indonesia, 2015:166).

In repressing crime rates and offense, we need anticipation by improving the process of education for the younger generation in the College. Education is the right place to build and improve the quality of students ' character as a younger generation for discipline and obedience towards the rule of law. It is indeed undeniable that the character issue remains a major focus of the talks to the people of Indonesia. Given the still prevalent problems of student indiscipline variety such as violating the code of conduct classes, late coming to the College, not the task of the teacher. As such it has become a habit that is widespread from the younger generation in particular students. Habit in carrying out the activities regularly and on time.

Discipline is good and polite behavior that contributes to act according to the rules of the code of conduct, behavior, run errands with organized and developed social conscience. Mumthas, Munavvir \& Gafoor, 2014:301). The attitude of discipline very necessary wherever and whenever an orderly and regular life. The attitude of discipline is indispensable in the education.

Discipline comes from the Greek "Disciplina" which shows the teaching and learning activities. In English the term "Disciple" which means following people learn under the supervision of a leader. Discipline very necessary students for success in education, particularly during their period of compulsory education, attended (Songul, 2009:242). The discipline needs modeling and giving reinforcement or punishment to build habit for students (Polat \& Akdag, 2013:885). Discipline as acts which govern human behavior changes (Gregory et al, 2010:483). However, students who do not act according to applicable rules, students get the punishment. Punishment in the school system are expected to improve discipline and enforce compliance in the school environment..

According to Chiu and Chow (2011:517) is a discipline a discipline is a consciousness of a person to administer the rules and regulations that are based on a positive attitude based on the code of conduct at the school. The existence of the school's code of conduct which constitutes the discipline in the schools of which there is discipline in the classroom can improve behavior in accordance with the rules and 
this is where teachers are likely to affect the existence of the attitude of discipline in the classroom. In addition, discipline in the classroom is very important to instill a sense of responsibility and maturity level of the students. The discipline also refers to one's actions to resolve the issue of the problems of mild to the heaviest which can interfere with learning in the classroom (Sharkey \& Jill, 2012:95).

Meanwhile, according to Nyabuto and Njoroge (2014:289) stated that the discipline is a very important element for the success of the student's academic achievement. School discipline plays an important role in the achievement of learning goals. As expressed by Osher, et al (2010:48) that school discipline devoted to teaching in the classroom and the students need a broader target and selfdevelopment. Based on the expression, discipline is very needed to support selfdevelopment students', particularly positive behaviors of students in the school.

Learning activity with discipline atmosphere will create a fun learning atmosphere. Hence, discipline can be applied by the teachers in the teaching and learning process. Teachers can develop and implement disciplines learning into student learning, that result to measure mastery learning of student (Rosanne et al., 2010:21). The discipline is very influential on the teaching and learning process. Discipline is not a tool to secure the classroom but are more important than education (Arum \& Velez, 2012:1).

In addition, students must also have an responsibility for carrying out the task. The responsibility must be able to be owned by a person to be a human character. The responsibility can be grown in a way evokes the consciousness of students. Responsibility is an act of someone who has consequences with the control of ourselves to others (Andrzej,
2017:58). The responsibility is not apart from something that should be applied with values.

The student's ability who have a responsibility. As expressed by Mackay (2017:94) students who have responsibility can create a conducive learning and develop cognitive students. This academic failure can be prevented by adopting responsibility to encourage a positive attitude which allows to control the behavior (Ruslana, 2017:2). Students will be more responsible in the learning activities if directly involved in the learning process.

Jeremy (2010:104) say that the teachers have the responsibility of teaching and learning activities in the classroom. Teachers are responsible for preparing students learning activities during the carrying out of learning. Likewise, students have the responsibility for the learning activities and assignments given by the teachers. It is similar with the opinion of Oers (2012:27) the teachers have the responsibility to study and instructed the students, it will be seen how big responsibility students toward outcome they do.

Training discipline and responsibility on the student aid students in behave according the rules that apply for the benefit of himself or another person. To realize the goal of discipline and responsibility should start from yourself and starting from the family. Parents can teach values of discipline through example or advice. Discipline refers to the way in which the control and penalty goal to train students, teaching, controlling, controlling student behavior conformed to regulations (Sandra, 2011:347).

Value clarification model is a model of the cultivation of the values to help individuals connect feelings and raise awareness of students towards personal moral dilemmas where that value can be 
analyzed (Josephine \& Vivian, 2015:3). Value clarification model gives emphasis on the cultivation of social values in students by providing awareness of value in themselves. Judge considered the identification process and socialization of a person who unconsciously incorporate themselves into the system of the value itself. In this case, the value clarification model is a model for instilling the values so that the students must put itself efficiently match their role as social beings.

According to the view of value clarification Model is the model of the most innovative learning towards moral values (Kirschenbaum, 2013:4). Meanwhile, according to Peate, Watts \& Wakefield (2013:299) values clarification model are learning model that leads a person in determining options as well as a positive value on himself. From the explanation that has been elaborated can be said that the model of supported values clarification process with the values underlying the most important things of value which is a quality that covers a very wide field such as moral values. Therefore, the value clarification model relating to behavior as well as a selection of human values that need to be noted as the goal of his life.

For learning model steps undertaken in this research based on opinion from Kosasih Djahiri (Umi chotimah, 2012:329) is divided into 6 i.e. 1) receipt of Stimulus that is in receipt of stimulus must be dilematis and contain conflicts values or morals so that students can receive learning material; 2) presents a Stimulus that is can be done through the activity of identifying problems (conflicts of values/morals); identify the facts contained in the stimulus; commonality in terms, determine the major problems that will be solved; 3) Determine a choice that is in determining choice, students are given the opportunity to respond to the position through individual choice, choice groups, clarifying the options; 4) test the reason in the reason test can be done by asking the student group class argument, dispute the argument through monitoring of argument for the sake of argument, the application events are have, examine the consequences of the application of These, and examine the possibility of activities; 5) false assertion and direction that is can be done through the conclusion of the student or group classes, conclusions and guidance by the teacher in accordance with the subject matter (the concept of values/norms/morals); and 6) Follow-up activities can be done by remidial, enrichment, and extra activities or exercises testing.

Model learning values clarification became one of the solutions to minimize misunderstandings in science. Value clarification model can improve behavior in family, schools and the community. In addition, the objectives of the value clarification model to the quality of teaching and learning that results in affective aspects (Lovat \& Clement, 2008:1). Furthermore, the purpose of the value clarification model contributed in creating a learning environment that is more fun and motivating student learning (Mihai Andronie and Petru Lisievici, 2016:400).

\section{Research Methods}

Type of this research is quantitative research with artificial experiments approach. This research was carried out at the University of PGRI. This research was carried out on the odd semester academic year 2016/2017. The time of the research was carried out during the months of October to December 2016. The population in this research is 145 students. 
While the sample in this study are 48 students. Data collection techniques on research is now self-peer assessment, observation and documentation.

Testing the validity of the instrument item in this study using a Bonferroni post hoc test. While reliability testing in this study using Cronbach Alpha. Data analysis techniques used in this research is a descriptive analysis and Multivariate analysis of variance (MANOVA). All test data analysis was done with the help of a computer program SPSS 22.0. Following is table 1 value of Cronbach Alpha.

Table 1. Cronbach Alpha Value

\begin{tabular}{llc}
\hline No. & Instrument & $\begin{array}{c}\text { Cronbach Alpha } \\
\text { Coefficient }\end{array}$ \\
\hline 1. & Discipline & 0.802 \\
2. & Responsibility & 0.782 \\
\hline
\end{tabular}

\section{Result and Discussion}

The results of the analysis show that there is a difference between experimental and control class over the establishment of student discipline in science. Because there are influences between the two groups, then the univariate test done on the results of observation of student discipline to know the attitude of the average of the variable where the maximum contribution of the paint against the influence of the two groups. As for the observation results of student disciplinary attitude can be seen in table 2 .
Table 2. Data Observation of students' Disciplinary

\begin{tabular}{|c|c|c|c|}
\hline Types of Tests & $\mathrm{N}$ & Mean & STD \\
\hline Pretest Control Class & 24 & 39.13 & 4.003 \\
\hline Pretest Classroom & 24 & 41.29 & 4.759 \\
\hline \multicolumn{4}{|l|}{ experiments } \\
\hline Posttest Control Class & 24 & 40.83 & 3.585 \\
\hline $\begin{array}{l}\text { Posttest Classroom } \\
\text { experiments }\end{array}$ & 24 & 47.33 & 6.141 \\
\hline
\end{tabular}

Based on the results of the statistical analysis descriptive observational data on student discipline attitude control experiment classes and classes before the treatments presented in the table shows that the average student's discipline stance observations on the control class of 39.13 and standard deviation 4.003 and average the results of observation of student discipline attitude on the experimental class of 41.29 and standard deviation 4.759. While the results of the observation data of student discipline attitude after treatment on the control of 40.83 class and standard deviation 3.585 as well as data observations on the experimental class of 47.33 and standard deviation 6.141. This indicates the existence of a discrepancy observation results of student disciplinary attitudes on class control and experimental classes before and after treatment. Describing the significant influence of the values clarification model's in science towards discipline assessment was done in a univariate on table 3.

Table 3. Comparison of Pretest and Posttest on experimental and controls class.

\begin{tabular}{llll}
\hline Types of Tests & N & Mean & STD \\
\hline Pretest Control Class & 24 & 48.50 & 4.908 \\
Pretest Classroom & 24 & 46.50 & 6.304 \\
experiments & & & \\
Posttest Control Class & 24 & 49.54 & 6.978 \\
Posttest Classroom & 24 & 55.58 & 8.577 \\
experiments & & & \\
\hline
\end{tabular}


Based on the results of the descriptive analysis shows that value clarification model gives positive effect toward disciplined using self-assessment in science. This can be seen on the initial conditions of students before and after the given treatment. Describing the significant influence of the value clarification model in science towards discipline using peer assessment was tested by univariate on table 4.

Table 4. Peer Assessment of Students' disciplinary

\begin{tabular}{llll}
\hline Types Of Tests & N & Mean & STD \\
\hline Pretest Control Class & 24 & 40.58 & 3.647 \\
Pretest Classroom & 24 & 39.83 & 6.253 \\
experiments & & & \\
Posttest Control Class & 24 & 44.54 & 8.129 \\
Posttest Classroom & 24 & 47.75 & 5.050 \\
experiments & & & \\
\hline
\end{tabular}

Based on the results of the descriptive analysis in table 4 show that learning the IPA value clarification model of positive effect against peer assessment of discipline students in science. This can be seen on the initial conditions of students before and after the given treatment.

Based on the MANOVA test result, value is $F=71,66 \%$ and value of signification is $\leq 0,05$, it can be inferred that $\mathrm{H} 1$ is accepted that proves the existence of a difference significant influence within the value clarification model toward discipline formation on pupils. Post hoc Bonferroni test shows the value is 48.00 , signification value is $\leq$ 0.05 . It can conclude that the value clarification model significantly influential to the formation of the discipline.

$$
\text { Implementation of value }
$$
clarification model there are steps of learning i.e. 1) Identify and clarify questions of values, 2) based on facts, 3) statement assessing the facts, 4) clarify the relevance of the facts, 5) the tentative value decision, 6) the principle of the test the value in making the decision (Meux and Milton, 1971: 31-61). One of them identify and clarify values discipline. The attitude of discipline in learning activities offers an effective way to address the problem of moral dilemmas (Senge et al., 2012:8).

As research Nurtia Lestari (2014) prove that the value clarification model improves the attitude of discipline, the results of research conducted by Agustina Wijayanti (2013) also showed that the model value clarification could bring an attitude positive student attitudes such as student discipline. In accordance with the statement of Arwen et al. (2013:157) that the model can be interpreted as values clarification. models of learning that helps a person to find values through behaviors, feelings, ideas, and through important choices in the create and act on in and through his life. Find a value through behavior, feeling, idea in itself is not a very easy thing in determining choice in acting in his life including on values of discipline.

Value clarification model help an individual in the situation until a choice among several relevant on student (Thomas, 2009:123). Research findings indicate that more precise value clarification model can be helped in the process of determining the relevant choice that emphasizes the process of learning and educational process especially increasing attitude can discipline students. Attitudes of student discipline will increase the positive behaviors of college students. As expressed by discipline can improve skills in self-control and positive behavior (Dupper, 2010:8).

The results of the analysis show that there is a difference between the experimental and control class over the establishment of responsibility. Because there are influences between the two 
groups, then the univariate test done on the results of observation of students' responsibility. As for the observation results of students' responsibility can be seen in table 5 .

Table 5 Data Observation Students' Responsibility.

\begin{tabular}{llll}
\hline Types of Tests & N & Mean & STD \\
\hline Pretest Control Class & 24 & 33.88 & 4.675 \\
Pretest Classroom & 24 & 41.71 & 4.695 \\
experiments & & & \\
Posttest Control Class & 24 & 35.75 & 3.161 \\
Posttest Classroom & 24 & 47.08 & 5.334 \\
experiments & & & \\
\hline
\end{tabular}

Based on the results of the statistical analysis descriptive observational data of students' responsibility attitudes on class control and experimental classes before the treatments presented in table 5. It was shows that the average results of observation of student responsibility attitude on experimental class using the value clarification model have significant influence towards the formation of attitudes of students' responsibility.

Describing the significant influence of the values clarification model in science course were used self-assessment, it can be seen on table 6.

Table 6. Comparison of the Pretest and Posttest experimental and controls Class.

\begin{tabular}{llll}
\hline Types of Tests & N & Mean & STD \\
\hline Pretest Control Class & 24 & 37.54 & 4.021 \\
Pretest Classroom & 24 & 35.79 & 5.838 \\
experiments & & & \\
Posttest Control Class & 24 & 45.96 & 3.155 \\
$\begin{array}{l}\text { Posttest } \text { Classroom } \\
\text { experiments }\end{array}$ & 24 & 48.59 & 4.597 \\
\hline
\end{tabular}

Based on the results of the descriptive analysis in table 6 show that learning the science with value clarification model are given positive effect to develop students' responsibility. This can be seen on the conditions of students before and after given treatment. On the initial conditions in the experiment class none of the students who reach them. It is indicating that values clarification model can be used to train responsibility on student's.

In addition, student's responsibility has assessed by peer-assessment. The result can be seen at table 7 .

Table 7. Peer Assessment of students' responsibility

\begin{tabular}{llll}
\hline Types Of Tests & N & Mean & STD \\
\hline Pretest Control Class & 24 & 33.83 & 5.362 \\
Pretest Classroom & 24 & 32.46 & 3.297 \\
experiments & & & \\
Posttest Control Class & 24 & 36.75 & 5.415 \\
Posttest Classroom & 24 & 37.79 & 4.054 \\
experiments & & & \\
\hline
\end{tabular}

Based on table 7 shows that value clarification model of positive effect ato train responsibility of the students. This can be seen on the conditions of students before and after given treatment.

The data shows that there is significant effect after implementing of value clarifying model in science course. Student's has responsibility to finish their task. This is obtained by performing a MANOVA analysis with sig. $\leq 0.05$, then the $\mathrm{H}_{0}$ was rejected, it means that there was significant influence between the value clarification models towards the formation of student responsibility. After the known presence of a difference significant influence then continued with the post hoc bonferroni test. The results of the analysis 
of the data supported by the observation of student responsibility.

Based on univariate test result, it can be obtained value of $\mathrm{F}$ is 7.789 and $\operatorname{sig} \leq$ 0.05 . It can be concluded that the $\mathrm{H}_{0}$ rejected. It means that there is significant influence. The significant influence value clarification model to trains responsibility of college students, conducted further tests post hoc bonferroni after being given the treatment. Post hoc bonferroni test generates a difference of mean is $49.88 \%$ and sig value $\leq 0.05$. i.e. 0.233 . These results prove that the values clarification model in science course toward the formation of student responsibility.

Implementation of values clarification model given influence on student responsibility. It can be seen on the stage of implementation of the learning. Teacher can give task and you can answer the questions. The opinion of the Sapriya (2014:343) explaining that the value clarification promotes it, look like, the intensive questioning, teachers can explore and develop the values contained in the learning material. In other hands, students have responsibility to finish their task. It can be improving students as self-directed learner.

Value clarification model have an aims to certain establishments, internalize, and behave in accordance with the values that have been choices and it is believed (Smith \& Knapp, 2010:258). Kemendiknas (2010:31) stated that indicators of responsibility is divided into 2 indicators for school or class. The indicator for school i.e. 1) reporting any activity carried out in the form of oral or written; perform the task without prompting; 2) shows the initiative to resolve problems within the scope of the nearest; 3) prevent fraud in the execution of the task.

While indicators of student responsibility for class i.e. 1) implementation of pickets on a regular basis; 2) roles and active in school activities; 3) filed proposal 2) perform tasks without being asked; 3) shows the initiative to resolve problems within the scope of the nearest; 4) prevent fraud in the execution of the task. This indicator covers all of the steps on the values clarification model. The indicator of responsibility for class, it was covers all steps of the value clarification model.

It can be said that values clarification model in science course has an impact on the formation of student responsibility. This model can be used as an alternative in the science course because it can make students are more active and motivated in class.

Differentiation the students discipline and responsibility analyzing are using the multivariate test. Analysis results showed that the value of sig. $\leq 0.05$, so it can be inferred that students discipline and responsibility. The value of $\mathrm{F}$ was obtained of $48.13 \%$ and sig 0.013 . This proves that the value clarification model has effect significantly to formation of discipline and responsibility of students.

The results of this study corroborate previous research conducted by Trisnawati (2013). The results of the study concluded that the application of the value clarification model can improve the discipline and responsibility of the student. More advanced Lisa (2000:20) that the purpose of the value clarification model is teaching a student behavior. Value clarification model can teach student to solve the problems with taking decisions together. Students are directly involved in decision making by providing solutions to problem solving (Holly et al., 2016:453).

Training discipline and responsibility for student can improve the effectiveness of learning. Refer to Arif (2014:388) stating that the teacher easily conveys the material and instilling the 
values of character in students by modelling. Furthermore, in the nation's character development book released by Kemendiknas (2010:11) state that the character education is integrated into school curriculum in either learning or culture of the school. The character of the discipline in this research was conducted during the learning process. In any learning model used, the students through the process or steps that demands discipline and attitude is the responsibility of the student.

Character education can be used as a reference in training discipline and responsibility for students, both in school /and higher education. This due to the decline in the values of humanity in students these days. The most frequent cases of bullying in schools are the main reason why discipline and responsibility need to be taught by the teacher through the cultivation of human values.

As one of the learning model, values clarification model provides the steps that can build discipline and responsibility in students themselves. It makes student became self-directed learner, because pupils have higher motivation to finish their task. Pupils can solve their problem in different situation. As directed learner, students must be developing their knowledge by knowing their learning style. Self-directed learner who people take the initiative without the help of others in diagnosing their learning needs, formulating goals, identifying human and material resources, and also evaluating learning outcomes.

Discipline and responsibility as a basic character for students to develop their capability as self-directed learner. In other hand, science equips the students how to reach scientific attitudes especially at laboratory activity. Beside of that, students are also taught how to find their own concept. Moreover, this model can be improving learning environment and developing respecting culture in the classroom. That is the cause of teaching character more important, especially discipline and responsibility.

\section{Conclusions and Suggestions}

The conclusion is the values clarification model can be used to train discipline and responsibility of the student with the sig $<0.05$. Further test results post hoc bonferroni value clarification model has an affects the formation of discipline and responsibility of the student. The learning model can serve as alternative learning in school..

\section{Reference}

Arif, M. (2014). Model pembelajaran sejarah dengan mengintegrasikan nilai dan karakter religius melalui teknik klarifikasi nilai. Jurnal Pendidikan Muslim, 1(1), 95-108.

Arum, Richard \& Velez, M. (2012). Improving learning environments: school discipline and student achievement in comparative perspective. Stanford: University Press.

Badan Pusat Statistik. (2015). Statistik Nasional Indonesia. Jakarta: BPS

Chiu, M.M. \& Chow, B.W.Y. (2011). Classroom discipline across fourty one countries: School, economic, and cultural differences. Journal of CrossCultural Psychology, 42 (3), 516-533.

Chotimah, Umi. 2012. Alternatif pembelajaran pendidikan kewarganegaraan sebagai upaya mencapai civic intelegence, civic participa tion dalam civic 
responsibility disampaikan dalam prisiding seminar nasional pendidikan 2012, Palembang 26 Juni 2012.

Contini, L. M. (2000). Values clarification destroys conscience: catholic culture. San Fransisco: Ignatius Press.

Coombs, J. R., \& Meux, M. (1971). Teaching strategies for value analysis. Journal of National Council for The Social Studies Yearbook, 29-74.

Djahiri, A.K. (1996). Menelusuri dunia afektif pendidikan nilai dan moral. Bandung: IKIP Bandung.

Dupper, D. R. (2010). A new model of school discipline: engaging students and preventing behavior problems. New York: Oxford University Press.

Gallagher, M.K. (2017). Succeeding together: schools, child welfare, and uncertain public responsibility for abused or neglected children. Canada: University of Toronto Press.

Gregory, A., Cornell, D., Fan, X., et al. (2010). Authoritative school discipline: High school practices associated with lower bullying and victimization. Journal of Educational Psychology, 102 (2), 483.

Kemendiknas. (2010). Bahan pelatihan: pengembangan pengembangan pendidikan budaya sekolah dan karakter bangsa. Jakarta: Kementerian Pendidikan Nasional dan Pengembangan Pusat Kurikulum.

Kilimci, S. (2009). Teachers perceptions on corporal punishment as a method of discipline in elementary schools. The Journal of International Social Research, 2 (8), 242-251.
Kirschenbaum, H. (2013). Value clarification in counseling and psychotherap: practical strategies for individual and group setting. New York: Oxford University Press.

Lestari, N. (2014). Upaya meningkatkan kedisiplinan dan prestasi belajar IPA materi contoh peraturan perundang-undangan di kelas $\mathrm{v}$ melalui model value clarification technique tipe perisai kepribadian di SD Al Irsyad 1 Purwokerto. Jurnal Pendidikan Dasar, 1 (1), 74-86.

Lisievici, P., \& Andronie, M. (2016). Teachers Assessing the Effectiveness of Values Clarification Techniques in Moral Education. Journal of Procedia Social and Behavioral Sciences, 217, 400-406.

Llewellyn, T. H. (2009). Values clarification. Shared Decision Making in Health Care: Achieving Evidence Based Patient Choice. Dalam Edwards Adrian \& Elwyn Glyn. Share Decision Making in Health Care: Achieving Evidence Based Patient Choice. New York: Oxford University Press.

Lovat, T., \& Clement, N. (2008). Quality teaching and values education: coalescing for effective learning. Journal of Moral Education, 37 (1), 1-16.

Mumthas, N. S., Munavvir, J., \& Abdul Gafoor, K. (2014). Student and teacher perception of disciplinary practices: types, reasons, consequences and alternatives. Journal of Online Submission, 2 (4), 301-308.

Naida, R. (2017). Study of organizational and pedagogical conditions for formation of responsibility in 
working activities with older preschool children. Journal of Innovative Solutions in Modern Science, 2 (11).

Njoroge, P.M. \& Nyabuto, A.N. (2014). Discipline as a factor in academic performance in Kenya. Journal of Educational and Social Research, 4 (1), 289.

Oers,V.B. (2012). Developmental education for young children: concept, practice and implementation. New York: Springer.

Osher, D., Bear, G.G., Sprague, J. R., et al. (2010). How can we improve school discipline. Journal of Educational Researcher, 39 (1), 48-58.

Peate, M., Watts, K., \& Wakefield, C. E. (2013). The value of values clarification in cancer-related decision aids. Journal of Patient Education and Counseling, 90 (2), 281-283.

Pieterse, A. H., de Vries, M., Kunneman., et al (2013). Theory informed design of values clarification methods: A cognitive psychological perspective on patient health-related decision making. Journal of Social Science \& Medicine, 77, 156163.

Polat, S., Kaya, S., \& Akdag, M. (2013). Investigating preservice teachers beliefs about classroom discipline. Journal of Educational Sciences Theory and Practice, 13 (2), 885-890.

Quinnell, R., Russell, C., Thompson, R. et al. (2010). Evidence based narratives to reconcile teaching practices in academic disciplines with the scholarship of teaching and learning. Journal of the
Scholarship of Teaching and Learning, 10 (3), 20-30.

Sapriya. (2014). Pendidikan IPS: konsep dan pembelajaran. Bandung: PT.Remaja Rosda Karya Offset.

Senge, P. M., Cambron, M. C., N., Lucas, T., et al. (2012). Schools that learn (updated and revised): A fifth discipline fieldbook for educators, parents, and everyone who cares about education. New York: Crown Business.

Sharkey, J. D. \& Fenning, P. A. (2012). Rationale for designing school contexts in support of proactive discipline. Journal of School Violence, 11 (2), 95-104.

Sierra, J.J. (2010). Shared responsibility and student learning: Ensuring a favorable educational experience. Journal of Marketing Education, 32 (1), 104-111.

Smith, E.T., \& Knapp, E.C.(2010). Sourcebook of Experiential Education: Key Thinkers and Their Contributions. Dalam Simon, S.B. Values Clarification. New York : Hart Publishing Company. 255-261.

Way, S. M. (2011). School discipline and disruptive classroom behavior: the moderating effects of student perceptions. Journal of The Sociological Quarterly, 52(3), 346-375.

Way, S. M. (2011). School discipline and disruptive classroom behavior: the moderating effects of student perceptions. Journal of The Sociological Quarterly, 52(3), 346-375.

Wijayanti, T. A. (2013). Implementasi pendekatan VCT dalam pembelajaran IPS Sekolah Dasar. Jurnal Ilmu Sosial, 10 (1), 72-79. 
Witteman, H. O., Scherer, L. D., Gavaruzzi, T., Pieterse., et al. (2016). Design features of explicit values clarification methods: a systematic review. Journal of Medical Decision Making,36(4),453-47. 